\title{
海底地形がアマモ場の形成に与える影響
}

\section{池田航助 $\left.{ }^{* 1}\right)$ 水町泰貴 1） - 大南真緒 2）：中島敦司 3)}

1）和歌山大学大学院システム工学研究科

2）和歌山県工業技術センター

3）和歌山大学システム工学部

\begin{abstract}
摘要 : 本研究では, 海底地形がアマモ場の形成に与える影響を明 らかにするために, 紀伊半島西部南東部に分布するアマモ場を対 象とし, その形成位置と海底地形の対応関係を調查した。紀伊半 島に抢けるアマモ場は, 主に波の影響が小さい入り江に形成され ていたが, 波の影響が大きい外海に面した地点でも岩礁などの海 底地形や防波堤の裏で形成されていた。そのため, 防波堤や岩礁 といった障害物が波の影響を緩和し, アマモやコアマモの流出が 阻害され, 定着したことでアマモ場の形成につながったと考えら れた。以上のことから, 岩礁などの海底地形が障害物となり, 波 の影響を緩和したことで, アマモ場の形成に大きな影響を与えて いることが示された。
\end{abstract}

キーワード : 海底地形, 岩礁, アマモ場, 砂面変動, 内海, 消波

\section{1. はじめに}

日本沿岸部には古くからアマモ（Zostra Marina L.）やコ アマモ（Zostra japonica Asch. et Graebn.）といった海草 が自生している。両種は, アマモ場と呼ばれる陸上の森林や 草原に類似した群落を浅海の海底に形成する。アマモ場には 水質浄化や海底の底質安定化, 微小生物の生息場など多様な 機能がある 7,9)。しかし, 高度経済成長時の浅海域の埋立て, 産業排水などの流入負荷の増加などが原因となり，藻場の消 失が確認されるようになった ${ }^{2)}$ 。

このような状況の中, アマモ場の重要性に注目が集まり, アマモ場の再生, 保全を目的とした調查や活動が行われてい る 5)。波浪の抑制や砂面安定性を確保する環境整備を行うこ とによって，アマモ場の再生に成功している事例がある 4)。 しかし, 生育条件を満たした地点でアマモ場の造成を行って も，アマモ場の拡大につながっていない事例も多い4)。

そのため, 潮流や透明度, 海水温などのアマモの生育条件 に関する研究やアマモ場造成手法に関する研究が数多く行わ れており，水産庁の示している指針では，アマモ場造成の適 地選定を行う際に，アマモなどの流出に関連する波浪，砂面 変動について調査するとしている 9)。これは造成したアマモ やコアマモの流出を防ぐための基準である。しかし，アマモ
場の形成条件と波の影響に関する研究は少ない。そこで本研 究では, 海底地形がアマモ場の形成に与える影響について明 らかにするため, 紀伊半島西部南東部に形成されているアマ モ場を対象として, アマモ場と海底地形の対応関係について の調查を行ったので，その結果を報告する。

\section{2. 調查方法}

\section{1 調查地概要}

本研究で調查対象地とした紀伊半島は北部が瀬戸内海式気 候, 南部が太平洋側気候に区分されているため, 北部と南部 では降水量が大きく異なっている。また, 潮岬を境界として, 黒潮の影響によってサンゴ礁の広がり方が異なっている ${ }^{6)}$ そのため, 隣接した地点で海水温や海流に大きな違いがある。

また, 紀伊半島はリアス式海岸や海岸段丘といった特殊な 海岸地形が発達し, 入り江が多くなっている ${ }^{10)} 。$

\section{2 調查方法}

\subsection{1 アマモ場の分布地点の特定}

2014 年, 2016 年の航空写真を利用し, 紀伊半島西部南東 部の砂浜が存在する地点内の海水面に陰影を確認できる地点 を抽出し, 現地調查を行った。現地調查では, 砂浜内に存在 するアマモやコアマモの切れ端などの漂着物, 海上の浮遊物

（以下, 痕跡）を徒歩により探索した。痕跡を発見した地点 をアマモ場分布地点とし, 調查地点内の陰影がアマモ場であ るかアマモ場以外の藻場であるかを陸上からの目視により判 定した。また，陰影がアマモ場であるかを判定できない地点 においては潜水調查を行うことで，陰影がアマモ場であるか の確認を行った。

\section{2 .2 海底地形々の対応関係}

現地調查によってアマモ場の形成を確認した地点を海上保 安庁が発行している 1:50,000 海底地形図上に記録した。ま た，海底地形図には防波堤が記されていなかったため, 航空 写真を利用し，海底地形図上に防波堤の位置を加筆した。こ れをもとに，アマモ場の形成を確認した地点における海底地 形を判読した。

\footnotetext{
*連絡先著者 (Corresponding author) : ₹ 640-8510 和歌山県和歌山市栄谷 930 E-mail : s174003@center.wakayama-u.ac.jp
} 


\section{3. 結果および考察}

3.1 紀伊半島西部南東部におけるアマモ場の形成要因

現地調査によりアマモ場の形成を確認した地点の分布とそ の立地を図-1 と表-1 に示した。本研究では, 紀伊半島西部 南東部のほぼすべての海岸線を調査したことで, 25 地点でア マモ場の分布を確認した。確認したアマモ場の多くは，橋杭 海水浴場や宇久井海水浴場などの海水浴場や深山湾や唐尾 湾, 田辺湾, 勝浦湾などの湾の中で形成されていた。また, 主に湾奥で形成されていることを確認した。特に，田辺湾に 関してはアマモ場の形成を確認した 25 地点のうち 12 地点が 分布していた。田辺湾は, 船をロープでつなぐ必要がないと いう意味で綱不知と呼ばれるほど波浪や潮流の影響が小さい という特徵がある 8)。また, 田辺湾以外でも, 紀伊半島西部 南東部におけるアマモ場は，外海に面した地点よりも湾奥と いった入り江や支湾に多く形成されていた。アマモ場の形成 を阻害する要因には波による影響が考えられており，水産庁 が提示しているアマモ場造成の適地選定の基準には「1 ケ月 の砂面変動が $10 \mathrm{~cm}$ 以下であること」とされている9)。砂面 変動は波浪や潮流によって引き起こされ，1 个月の砂面変動 が $10 \mathrm{~cm}$ を超える場所では，アマモやコアマモが定着する前

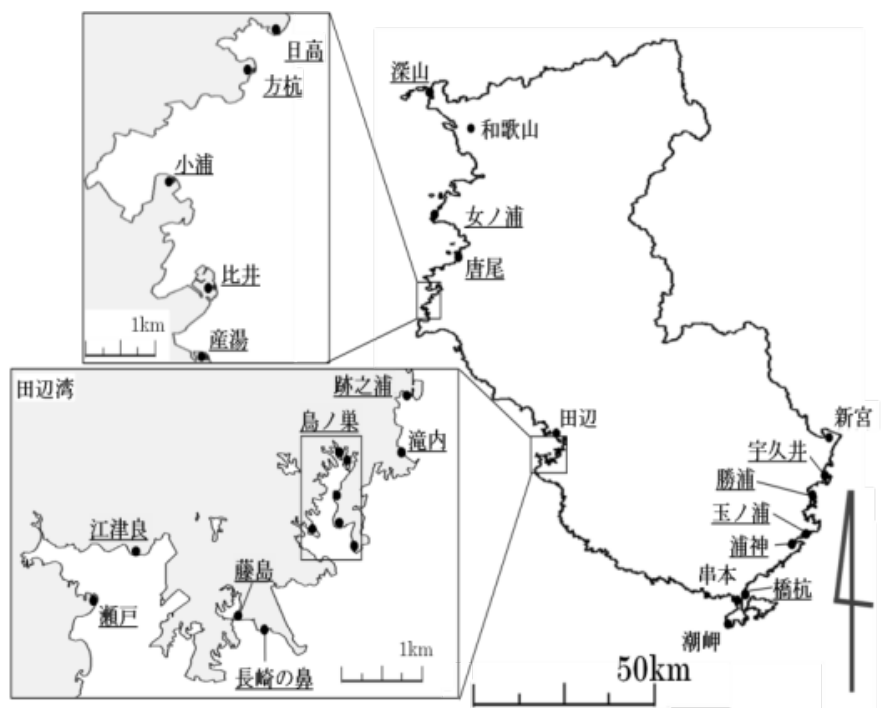

図-1 紀伊半島におけるアマモ場の分布地点（下線部：調査地）

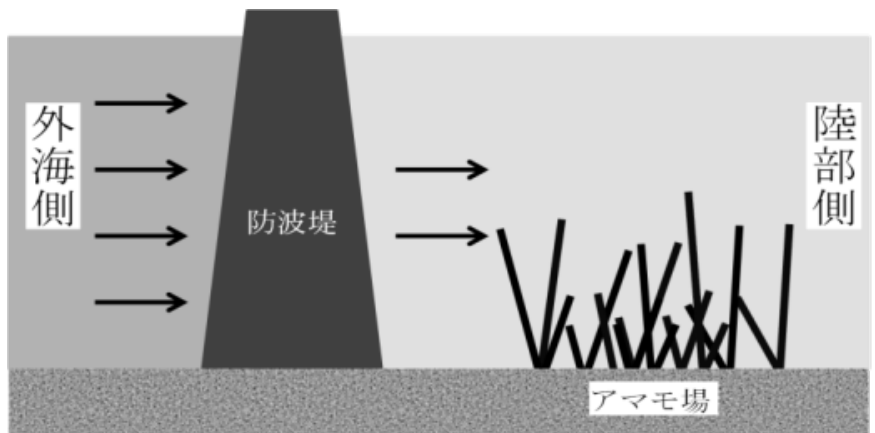

図-2 防波堤の内側に存在するアマモ場の模式図
に流出する可能性が高くなる ${ }^{1,3)}$ 。そのため, 紀伊半島におい ても, 波浪や潮流, 砂面変動が小さい田辺湾や湾奥で多くの アマモ場が形成されたと考えられた。

アマモ場を確認した地点において, 形成されたアマモ場は, 漁港内や海水浴場内に位置していた。また, 防波堤がある地 点では，防波堤の内側に形成を確認した。図-2に防波堤の内 側におけるアマモ場の形成位置の模式図を示した。防波堤が ある地点のうち, 女ノ浦では, 2010 年に消波ブロック据付工 事が行われ，防波堤が建設された。その後の 2016 年の現地 調査により，アマモ場が新たに形成されたことを確認した。 また，過去に形成を確認できなかった地点においても，防波 堤などの障害物の建設によって, 波浪や潮流の分散や砂面変 動が緩和されたことで, アマモやコアマモが流出せずに定着 し，アマモ場が形成されたと考えられた。

以上のことから，紀伊半島におけるアマモ場の形成要因に は，波浪や潮流，砂面変動による影響が挙げられる。

3.2 海底地形との対応関係

現地調査により特定したアマモ場の分布地点を記録し，海 底地形図を重ねた。その図を図-3から図-6に示した。これら をみると，アマモ場が形成されていた地点のうち，15 地点は 入り江に属しており, 深山, 女八浦, 日高, 方杭, 比井, 産 湯, 江津良, 瀬戸, 橋杭, 勝浦の 10 地点は外海に面した地 点であった。

外海に面した地点のうち, 深山, 女ノ浦, 日高, 橋杭の 4 地点には地点内に防波堤が存在した。また, 比井, 産湯, 江 津良, 瀬戸の 4 地点は漁港となっていた。これらの地点のよ うに外海に面した地点であっても，波浪や潮流を緩和する障 害物が存在するとアマモ場が形成されると考えられた。

表-1 アマモ場が存在する地点の立地

\begin{tabular}{|c|c|c|c|c|c|}
\hline & 入り江 & 外海 & 防波堤 & 漁港 & 海水浴場 \\
\hline 唐尾 & 0 & & & & 0 \\
\hline 小浦 & 0 & & & & 0 \\
\hline 跡之浦 & 0 & & & & \\
\hline 滝内 & 0 & & & & \\
\hline 鳥ノ巣 & 0 & & & & \\
\hline 長崎の鼻 & 0 & & & & \\
\hline 藤島 & 0 & & & & \\
\hline 浦神 & 0 & & & & \\
\hline 玉ノ浦 & 0 & & & & 0 \\
\hline 宇久井 & 0 & & 0 & 0 & 0 \\
\hline 深山 & & 0 & $\bigcirc$ & & \\
\hline 女ノ浦 & & $\bigcirc$ & 0 & & 0 \\
\hline 日高 & & 0 & 0 & & 0 \\
\hline 方杭 & & 0 & & & 0 \\
\hline 比井 & & 0 & & 0 & \\
\hline 産湯 & & 0 & & 0 & 0 \\
\hline 江津良 & & 0 & & 0 & 0 \\
\hline 瀬戸 & & 0 & & 0 & 0 \\
\hline 橋杭 & & 0 & 0 & & 0 \\
\hline 勝浦 & & 0 & & & \\
\hline
\end{tabular}



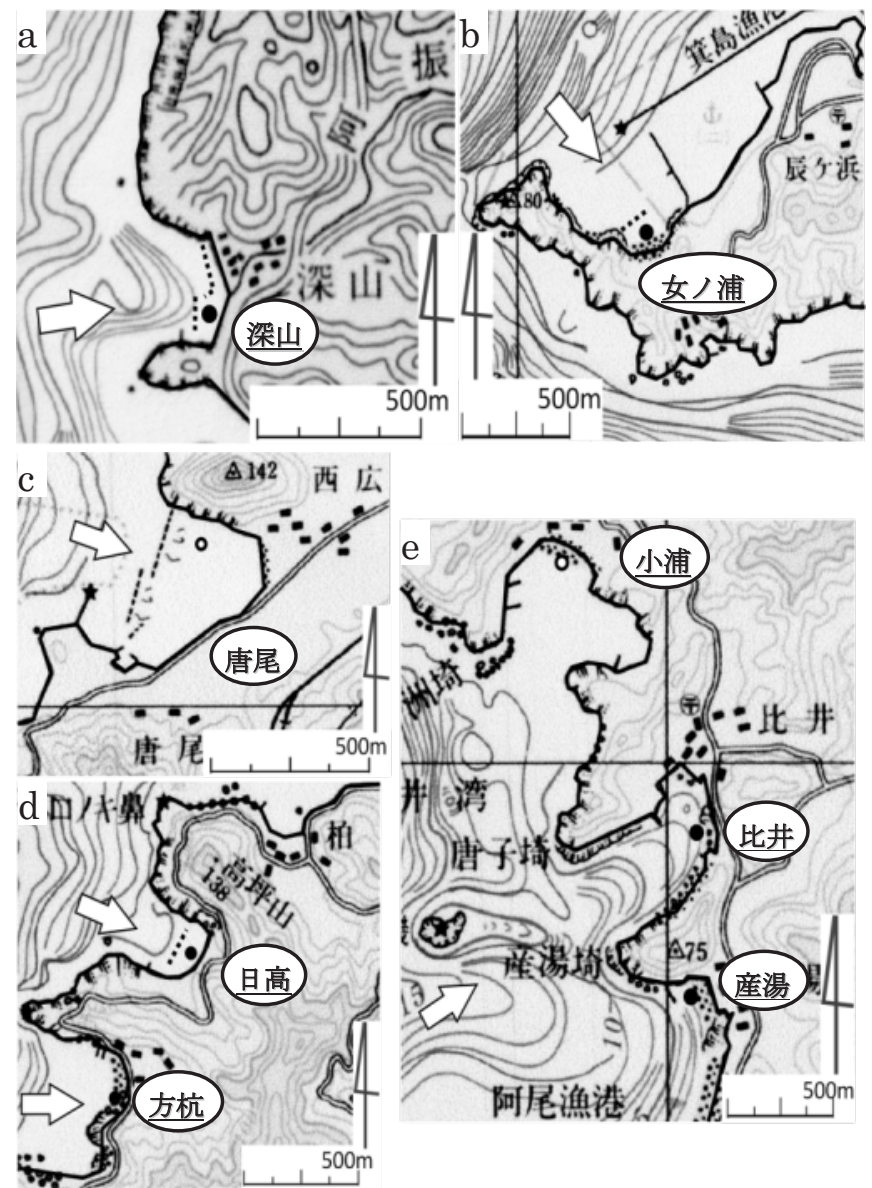

図-3 紀伊半島北部に分布するアマモ場と海底地形

（矢印：波の向き, 白丸：入り江内のアマモ場, 黒丸 : 外 海に面したアマモ場, 深山, 女ノ浦, 日高における点線： 防波堤） $\mathrm{a}$ ：深山，b：女ノ浦， $\mathrm{c}$ ：唐尾， d : 日高，方杭， $\mathrm{e}$ : 小浦, 比井, 産湯 (出典 : 海底地形図改変)

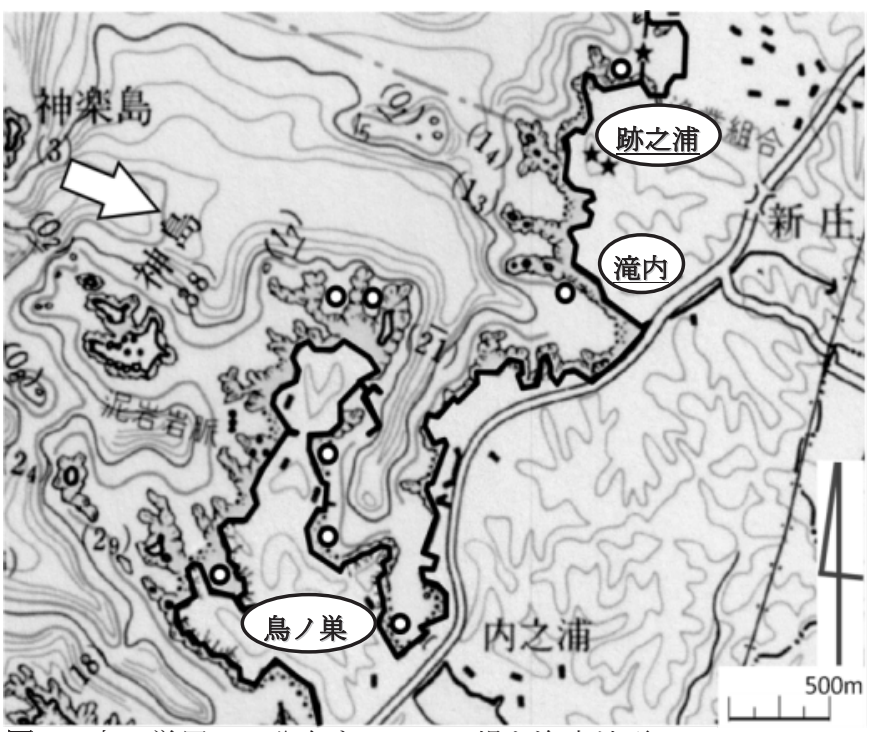

図-4 鳥ノ巣周辺に分布するアマモ場と海底地形

（矢印：波の向き，白丸：入り江内のアマモ場）

（出典 : 海底地形図改変）
しかし，方杭，勝浦の 2 地点に関しては地点内に防波堤や 漁港は存在しなかった。陸上からの目視によっても，波浪や 潮流に対する障害物が確認できなかった。そのため, これら の場所は波の影響が大きい地点であると判断され, 消波設備 の有無だけでは外海に面した地点における群落の成立条件に ついての説明ができなかった。

そこで, 図-3 から図-6 を用いてアマモ場の形成位置と海底 地形の対応関係を調べた。その結果，消波設備が存在してい ない方杭, 勝浦には, 外海とアマモ場の間に岩礁が存在して いることがわかった。そのため，岩礁などの海底地形が波の 影響を緩和することで，外海に面した地点においてもアマモ 場は形成されると考えられた。

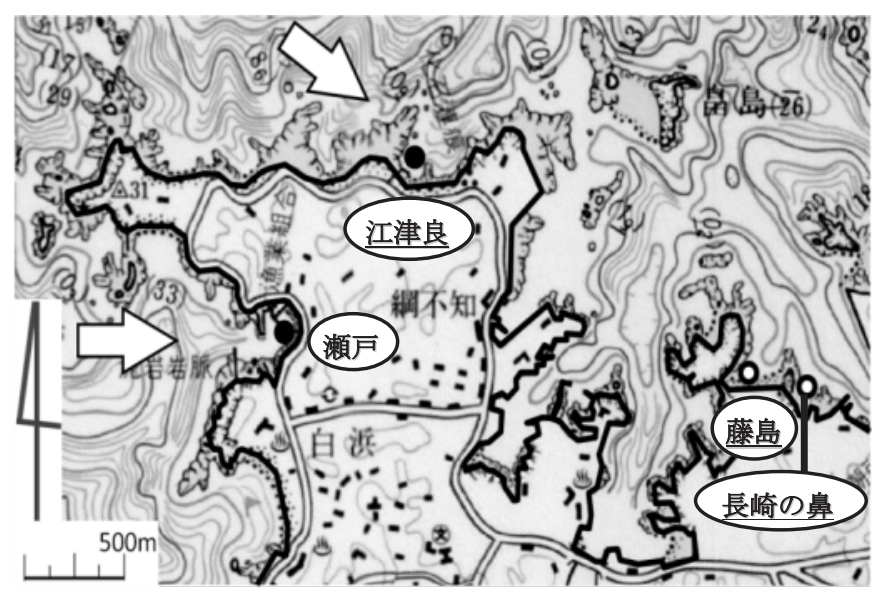

図-5 江津良周辺に分布するアマモ場と海底地形

（矢印：波の向き, 白丸：入り江内のアマモ場, 黒丸 : 外

海に面したアマモ場）（出典：海底地形図改変）

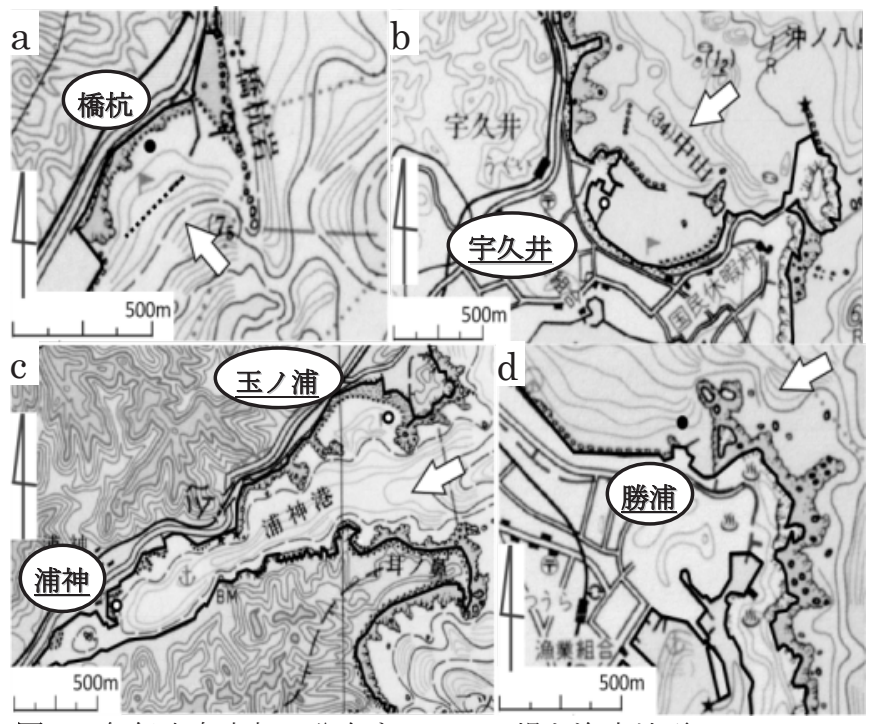

図-6 紀伊半島東部に分布するアマモ場と海底地形

(矢印 : 波の向き, 白丸 : 入り江内のアマモ場, 黒丸 : 外 海に面したアマモ場，橋杭における点線：防波堤） $a$ : 橋杭, b : 宇久井, c : 玉ノ浦, 浦神, $d$ : 勝浦 (出典: 海底地形図改変) 

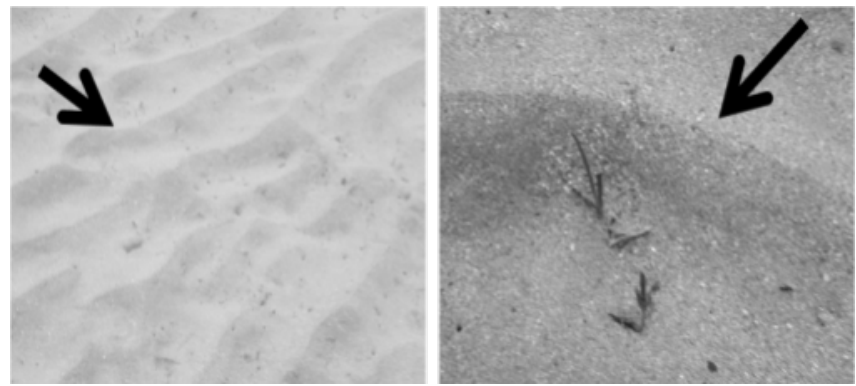

図-7 小浦に形成された砂れんと砂れんの裏に自生するアマモ （矢印の向き：波の向き）（撮影 : 2015 年 11 月 28 日）

また，鳥ノ巣（図-4）や玉ノ浦（図-6）といった入り江に 属する地点でも岩礁に囲まれた場所でアマモ場が存在した。 そのため，湾奥や支湾などの入り江においても，岩礁などの 海底地形が障害物となり，波の影響を緩和することで，岩礁 に囲まれた場所やその裏側，防波堤などの消波設備の内側に アマモ場が形成されると考えられた。

一方で, 2015 年に現地調查を行った際, 図-7 に示したよ うに砂れんが形成された地点においても，アマモやコアマモ が生育していることを確認した。砂れんは波の影響が大きい ところで形成される。そういった地点は，アマモやコアマモ の定着が難しいため，アマモ場造成地としては適していない とされている 9)。しかし，紀伊半島においては，図-7に示し たように密集はしていないが，波の向きとは反対側の砂れん の裏にアマモが生育していた。そのため，砂れんが形成され るような波の影響が大きい場所であっても，形成された砂れ ん自体が障害物となり，波の影響を緩和させる可能性がある と考えられた。

以上のことから，アマモ場は主に波の影響が小さい浅水域 で形成されるが，波の影響が大きい浅水域であっても，図-8 のように，防波堤や岩礁などの障害物が存在すると形成され ると考えられた。波浪や潮流は障害物と衝突することで，そ の力が分散し, 障害物の裏側における波の影響が緩和される。 その結果，岩礁などの海底地形によって，アマモやコアマモ の流出が阻害されるもしくは流出したアマモやコアマモが捕 捉されることで，障害物の裏側で定着すると考えられた。

\section{4. まとめ}

本研究によって，波の影響を大きく受ける外海に面した浅 海域であっても，波の影響が小さい入り江であっても，岩礁 などの海底地形が波の影響を緩和し，アマモやコアマモの流 出を防ぎ，アマモ場の形成につながることが示された。

しかし，本研究は，形成位置と海底地形に注目し，その対 応関係を明らかにしたものであり，アマモ場の形成地点内に おける海流の向きや流速との対応関係までは明らかにできて いない。そのため，海底地形が波の影響を緩和することで， アマモ場の形成に影響を与えていることを示すために，海流 の向きや流速を測定し, 海底地形が外海からの波の影響をど

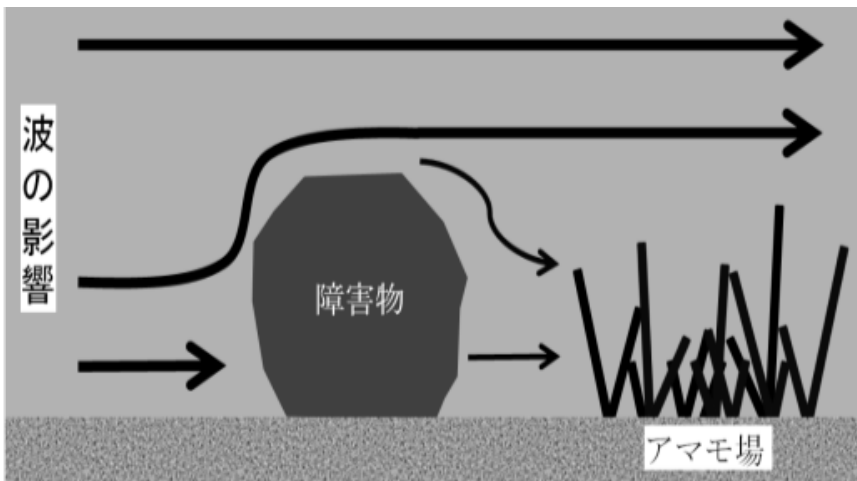

図-8 防波堤や障害物の裏側に形成されるアマモ場の模式図

（矢印の向きが波の動き，太さが波の大きさ）

の程度, 緩和しているのかをより詳細に調査する必要がある。

また，波の影響が大きく，砂れんが形成される浅海域にお いて，波の向きと反対側に位置する砂れんの裏側にアマモが 生育していた。このことから，砂れんのような小さく安定性 が低い障害物であっても，アマモやコアマモの流出を防ぐ可 能性があると考えられた。そのため, 波の影響を緩和させる 障害物の大きさや安定性などの基礎情報を明らかにすること も重要になると考えられた。

\section{引用文献}

1）團昭紀・森口朗彦・三橋公夫・寺脇利信（1998）鳴門地先 におけるアマモ場と底質および波浪との関係. 水産工学, 34(3): 299-304

2）藤原宗弘（2013）瀬戸内海浅海域におけるアマモ場造成技 術に関する研究. 香川県水産試験場研究報告, 14: 1-4.

3）平岡喜代典・杉本憲司 - 太田誠二・寺脇利信 - 岡田光正 （2005）葉上浮泥による光量低下と砂面変動がアマモ場の 分布に及ぼす影響-広島湾でのケーススタディー。水環境学 会誌, 28(4): 257-261.

4）平岡喜代典・杉本憲司 - 太田誠二 ・ 寺脇利信 - 岡田光正 （2006）アマモ場再生事例と実証試験に基づくアマモ場再 生の検討. 環境科学会誌, 19(3): 241-248.

5）金澤 剛・明松正二・多賀 博 - 稲田 勉（2005）も場衰 退海域におけるアマモ場再生試験について. 海洋開発論文 集,21: 677-682.

6）環境省自然環境局生物多様性センター (2015) 平成 26 年 度モニタリングサイト 1000 サンゴ礁調査報告書. pp. 97-104.

7）小松輝久・佐川龍之・三上温子（2006）干潟生態系におけ る藻場の分布とその役割. 地球環境, 11(2): 207-213.

8）佐々木政一（1998）紀伊国万葉歌碑. 新和歌山新報社，151 pp.

9）水産庁・マリノフォーラム 21（2007）アマモ類の自然再生 ガイドライン.

10）米倉伸之（1968）紀伊半島南部の海岸段丘と地殼変動. 地 学雑誌, 77(1): 1-23.

(2017 年 6 月 19 日受理 $)$ 